\title{
The stomatology villaclareña present in the fight against Ebola in sierra Leone
}

\begin{abstract}
Summary
Introduction: Along with the Cuban doctors and nurses who faced Ebola in Sierra Leone, a Stomatologist graduated from the Faculty of Stomatology in Santa Clara participated in a worthy job.

Objective: Exhibit the work done by Patrick Don Davis with the Cuban Medical brigade, reflecting the knowledge and values achieved in his training as a graduate professional in Villa Clara. With this work we intend to recognize the effort and sacrifice of those who were at the side of their people and the Cubans in such a risky and difficult mission.

Development: We approach the work done by Dr. Patrick Don Davis graduated from the Faculty of Stomatology in Villa Clara and his collaboration with the Cuban medical brigade that faced Ebola in Sierra Leone showing self-denial, spirit of solidarity and professionalism in their performance. The data was obtained in the field and compiled in the reports of the brigade for this assignment by those responsible for the mission.
\end{abstract}

Conclusion: It concludes summarizing what it meant for the brigade of doctors and nurses in combat against a dangerous epidemic the participation of a Stomatologist which had not been foreseen and was a very valuable experience.

Keywords: Internationality, medical cooperation, history, medical training, nurses, dangerous epidemic, humanity, sanitary disaster, proclaimed victorious
Volume 2 Issue 3 - 2018

\author{
Bárbara E Cabrera Menendez,' Rafael R \\ Corona Pérez ${ }^{2}$ \\ 'Consulting Professor, School of Stomatology UCM-VC, Cuba \\ ${ }^{2}$ Consulting Professor, Specialist of I degree in General Hygiene \\ and II, Cuba
}

Correspondence: Rafael R Corona Pérez, Profesor Consultante de la UCM-VC, Universidad de Ciencias Médicas de Villa Clara, Cuba, Tel 42207043,

Email rafaelcorona@infomed.sld.cu

Received: May 09, 2018 | Published: May 16, 2018

\section{Introduction}

The participation of Cuban health professionals in the world campaign against Ebola is valued as an unprecedented event in the history of humanity, in the history of Cuba and in the history of Cuban medicine, which due to its transcendence. It must be studied, investigated and disclosed. Their contributions and experiences must be part of the undergraduate and postgraduate programs not only for the historical aspects, but also for their impact on the medical sciences and for being an example of altruism characteristic of revolutionary professional ethics. Testimonials what happened in those months in which the intellect, perseverance, courage and struggle for life were imposed in the face of sanitary disaster and proclaimed victorious are the basis for the studies and research that our health professionals must carry out as part of agreements of the Extraordinary Summit of the Bolivarian Alliance for the Peoples of Our America- Peoples Trade Treaty (ALBA-TCP) of 20 October 2014 that emphasized the Ebola epidemic. The Summit took a diligent stand before the UN Secretary General's call to face the dangerous epidemic, according to the Granma newspaper in a single edition. The special envoy of the Secretary General of the United Nations, David Nabarro in his speech said: "I want to thank the people of Cuba for sending some of their best doctors and nurses to fight against Ebola in West Africa and the Cuban President Raul Castro to inaugurate it. On Tuesday, October 21, he said "the best way to avoid being affected by the virus is to prepare intensely. ${ }^{1}$ Along with the Cuban doctors and nurses who faced the Ebola epidemic in Sierra Leone, a Stomatologist graduated from the School of Stomatology in Santa Clara, who unconditionally supported the Cuban brigade and joined the "Henry Reeve " brigade since the arrival of the Advanced on September 22, 2014, when he ratified his commitment to the Cuban people he considered part of.

\section{Objective}

Exhibit the work carried out by Patrick Davis and the Cuban Medical brigade, reflecting the knowledge and values achieved in his training as a graduate professional in Villa Clara. With this work we intend to recognize the effort and sacrifice of those who were at the side of their people and the Cubans in such a risky and difficult mission.

\section{Development}

Arriving in Free Town, capital of Sierra Leone, the members of the outpost lodge in the house of the head of the permanent medical brigade, Eneida Álvarez, who was already several years in the country and endured the Ebola epidemic since March 2014. On the afternoon of Sunday, September 22, newly installed, I will visit a sierraleonés that I invite you to share some cold cuts and welcomes. Dr. Corona describes this encounter: R esultó a very pleasant surprise in the midst of so many contingencies, we meet one of the students trained at the Medical University of Villa Clara. I did not imagine the reunion. I recognized him immediately because in his student days my wife was the Dean of Foreign Scholars of the Superior Institute of Medical Sciences of Villa Clara and we frequented. For me it was very stimulating to appreciate the human, moral and bravery values of those who are proud of having studied in Cuba, and have the behavior of a true internationalist professional, remembering the distant year of 1960 when Fidel when referring to professionals He said: " Men of Science, at the Service of Humanity. "Patrick Don Davis, a native of Si erra Leona, completed his career at the School of Stomatology of Villa Clara some 20 years ago and became a relevant and professional who did not leave his people in this grave emergency as can be seen in the letter sent by the president of the country to President Raúl Castro: 
"(...) it is with sadness, anxiety and despair that I am writing to tell you about the unprecedented outbreak of the terrible Ebola virus that is devastating our sub region and claiming the lives of our citizens, which include front-line health workers. This terrible scourge has created a frightening health crisis that threatens peace, security and stability in Sierra Leone. “

“(...) like a true friend of Sierra Leone, I am writing to you in this moment of affliction to help us with the necessary specialists and technicians who will make use of their experience to combat this serious health crisis".

Patrick's support was total, offering his house and the necessary food to deploy the leadership of the emergent brigade, which was kept as a possibility for future contingencies as it happened with the blockade to the operations in dollars to the brigade that prevented the payment to the hotels and that could be solved for international pressure in favor of Cuba. To count on the help of Patrick was fundamental for the recognition of the country, the ways of communication and the appreciation of the prevailing epidemiological and biological situation, its customs and traditions and to establish relations with the state and social institutions necessary to be able to receive the brigade on October 2, as it really happened. In November, our ambassador sent us the statements of Dr. Gao Fu, director of the Chinese CDC, asking us to see them in the context of the meetings held by the Cuban Medical Brigade with the authorities of Sierra Leone. In them, the doctor said:"... there are many organizations and agencies working, but most do not trust the government or the local population and that is not good, the government should be in charge of the fight against virus". The Chinese official insists on the lack of confidence in his government by the people. This is the reason why it continues to deny the existence of the disease and does not comply with preventive measures. ${ }^{2}$ Patrick's participation was of great importance in the coordination with the structures of the government and with the organizations that faced the epidemic at the same time as he explained to us the picture of social deterioration and the religious beliefs that made the fight against the epidemic more difficult. Tradition of bathing the relatives of the deceased with the water used in washing the corpses, which was the main source of contamination of the disease due to the high viral load contained in the water.

The function of Patrick as a stomatologist was decisive in the attention to the brigadistas, because the haste in the exit of the brigade did not allow the stomatologic discharge of the majority of the collaborators and the oral affections for the work in the red zones were dangerous. The great contagiousness of the ebola virus. The stomatology office was located in the national hospital Conaught, where most of the Cuban doctors worked, being responsible for the coordination with the national specialists for the attention of our personnel when the brigade did not have any specialty, as was often the case with ophthalmology, urology, endocrinology and especially with the performance of clinical laboratory examinations and medication management since the supply from Cuba began in the month of January. Their support was essential in carrying out procedures and coordination for autopsy, funeral and burial of Reinaldo Villafranca so complicated the process and the lack of knowledge - regulation is national by the leadership of the brigade and the newly incorporated charge d'affaires for Sierra Leone of the Cuban Embassy based in Ghana.

\section{Conclusion}

The professional training of students from poor countries, often forgotten, fulfills the revolutionary principle of internationalism and humanism that characterizes the Cuban people and is reverted with the friendship and solidarity it receives from the fraternal peoples. The experience lived with the selfless support of Patrick Don Davies is no exception and should be recognized and disseminated as part of the noble history that characterizes Cuban medical collaboration. The frequency of the need for dental care by collaborators recommends the inclusion of stomatologists in the "Henry Reeve" contingent brigades.

\section{Acknowledgements}

None.

\section{Conflict of interest}

The authors declare there is no conflict of interest.

\section{References}

1. Castro Ruz R. Speech at the inauguration of the extraordinary summit of ALBA-TCP on Ebola. Havana: Office of the Council of State; 2014.

2. Corona Pérez RR. Ebola epidemic in Africa: Cuban medical experience in this international health emergency (I). EDUMECENTRO. 2018;10(1):207-215. 